\title{
A New Heteroleptic Biquinoline Ruthenium(II) Sensitizer for Near-IR Sensitization of Nanocrystalline $\mathrm{TiO}_{2}$
}

\author{
Surya Prakash Singh, ${ }^{1}$ K. S. V. Gupta, ${ }^{1}$ P. Srinivasu, ${ }^{1}$ \\ Ashraful Islam, ${ }^{2}$ and Mohammad Rezaul Karim ${ }^{3}$ \\ ${ }^{1}$ Inorganic and Physical Chemistry Division, CSIR-Indian Institute of Chemical Technology, Uppal Road, Tarnaka, \\ Hyderabad 500607, India \\ ${ }^{2}$ Photovoltaic Materials Unit, National Institute for Materials Science, 1-2-1 Sengen, Tsukuba, Ibaraki 305-0047, Japan \\ ${ }^{3}$ Center of Excellence for Research in Engineering Materials (CEREM), College of Engineering, King Saud University, \\ Riyadh 11421, Saudi Arabia
}

Correspondence should be addressed to Surya Prakash Singh; singhspiict@gmail.com

Received 22 June 2012; Accepted 14 October 2012

Academic Editor: Ahmed El-Shafei

Copyright (c) 2013 Surya Prakash Singh et al. This is an open access article distributed under the Creative Commons Attribution License, which permits unrestricted use, distribution, and reproduction in any medium, provided the original work is properly cited.

Ruthenium(II) complex containing cis- $\left[\mathrm{Ru}\left(\mathrm{H}_{2} \mathrm{dcbiq}\right)(\mathrm{L})(\mathrm{NCS})_{2}\right]$, where $\mathrm{H}_{2}$ dcbiq $=4,4^{\prime}$-dicarboxy-2,2' -biquinoline and $\mathrm{L}=4,4^{\prime}$ di-tert-butyl-2-2' -dipyridyl coded as SPS-02, was synthesized and fully characterized. This complex showed appreciably broad absorption range. The new complex was used as photosensitizer in nanocrystalline $\mathrm{TiO}_{2}$ dye-sensitized solar cell application. cis$\left[\mathrm{Ru}\left(\mathrm{H}_{2} \mathrm{dcbiq}\right)(\mathrm{L})(\mathrm{NCS})_{2}\right]$ (SPS-02) achieved efficient sensitization of nanocrystalline $\mathrm{TiO}_{2}$ over the whole visible range, extending into the near-IR region (ca. $1000 \mathrm{~nm}$ ) with superior short-circuit photocurrent density $\left(J_{\mathrm{sc}}=9.13 \mathrm{~mA} \mathrm{~cm}^{-2}\right)$ and conversion

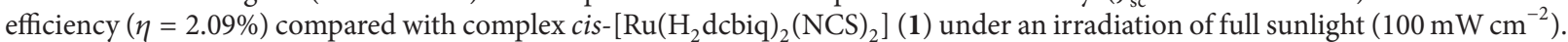

\section{Introduction}

Dye-sensitized solar cells (DSSCs) have been developed as an efficient, low-cost alternatives to the silicon technology during the last years [1-6]. Based on dye-sensitized nanocrystalline titanium dioxide as photoelectrode, power conversion efficiencies of over $11 \%$ have been reached [7]. In order to improve the efficiency of DSSCs, the sensitizer should absorb photons in the near-IR region as well as over the entire visible region of the solar spectrum. Considerable efforts have been made on 2,2'-bipyridineand $2,2^{\prime}: 6^{\prime}, 2^{\prime \prime}$-terpyridine-based ruthenium complexes to improve the light-harvesting properties through introduction of extended $\pi$-conjugated system [6]. 2,2'-biquinoline has low $\pi$-energy level than both $2,2^{\prime}$-bipyridine and $2,2^{\prime}: 6^{\prime}, 2^{\prime \prime}$ terpyridine and has potential to improve IR absorbance with its analogues Ru complexes. Arakawa and coworkers studied solar cells based on $\mathrm{TiO}_{2}$ sensitized with homoleptic ruthenium complexes containing $4,4^{\prime}$-dicarboxy-2,2' -biquinoline cis- $\left[\mathrm{Ru}\left(\mathrm{H}_{2} \mathrm{dcbiq}\right)_{2}(\mathrm{NCS})_{2}\right](\mathbf{1})$ and reported that these solar cells have an enhanced red response in the near-IR region, but the solar cell performance was decreased due to the poor electron injection efficiency on to $\mathrm{TiO}_{2}$ [8]. As a part of our research program in the development of new photosensitizers [9-14], we have strategically designed a heteroleptic dye SPS02 (Figure 1) having both 4,4'-di-tert-butyl-2-2' -dipyridyl and $4,4^{\prime}$-dicarboxy-2,2' -biquinoline in the same molecule, which exhibits better performance in the IR region.

\section{Experimental}

2.1. Synthesis of SPS-02. $\left.\left[\mathrm{RuCl}_{2}(p \text {-cymene })\right]_{2}\right](0.228 \mathrm{~g}$, $0.37 \mathrm{mmol})$ was dissolved in DMF $(30 \mathrm{~mL})$, and $4,4^{\prime}$-di-tertbutyl-2-2' -dipyridyl $(0.20 \mathrm{~g}, 0.74 \mathrm{mmol})$ was added. The reaction mixture was heated at $80^{\circ} \mathrm{C}$ under nitrogen for $2 \mathrm{~h}$, and then $4,4^{\prime}$-dicarboxy-2,2' -biquinoline $(0.313 \mathrm{~g}, 0.74 \mathrm{mmol})$ was added. The reaction mixture was refluxed at $160^{\circ} \mathrm{C}$ for 


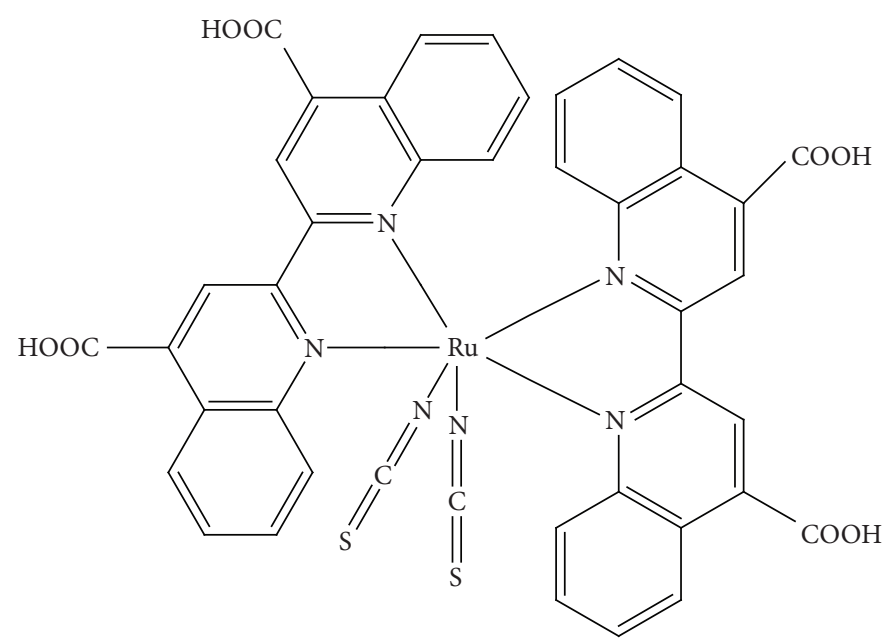

(a)

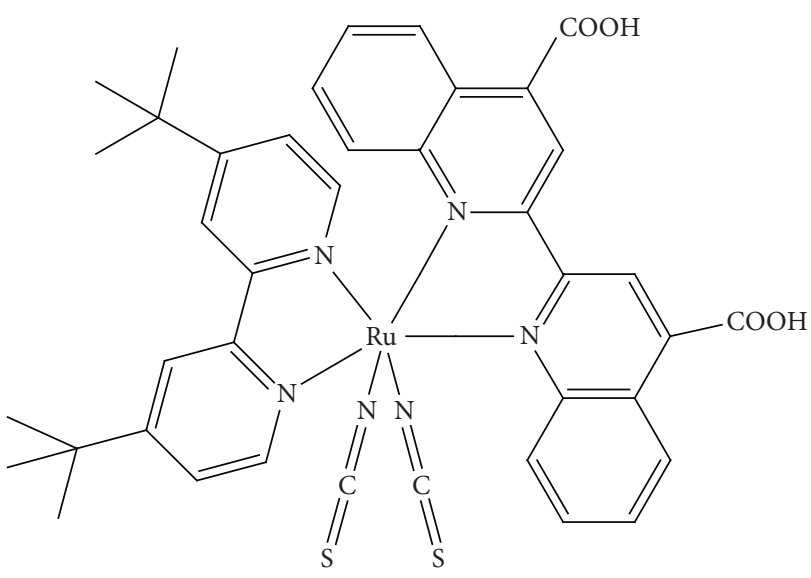

SPS-02

(b)

FIGURE 1: Chemical structures of $\mathbf{1}$ and SPS-02.

another $4 \mathrm{~h}$ under reduced-light conditions to avoid lightinduced cis to trans isomerization. An excess of $\mathrm{NH}_{4} \mathrm{NCS}$ $(1.78 \mathrm{~g}, 23.4 \mathrm{mmol})$ was then added to the reaction mixture, which was then heated at $130^{\circ} \mathrm{C}$ for a further $5 \mathrm{~h}$. The solvent was removed with a rotary evaporator. Water was added to the resulting semisolid to remove excess $\mathrm{NH}_{4} \mathrm{NCS}$. The water insoluble product was collected, washed first with distilled water and then with diethyl ether, and dried. The crude complex was dissolved in a solution of sodium hydroxide $(0.4 \mathrm{~g})$ in water $(10 \mathrm{~mL})$. The concentrated solution was charged onto a Sephadex LH-20 column and eluted with water. The main brown band was collected and concentrated to $3 \mathrm{~mL}$. The required complex was isolated upon addition of a few drops of $0.01 \mathrm{M}$ aqueous $\mathrm{HNO}_{3}$. Complex SPS-02 was obtained after membrane filtration as brownish solid $78 \mathrm{mg}$. Anal. calcd for $\mathrm{C}_{40} \mathrm{H}_{36} \mathrm{~N}_{6} \mathrm{O}_{4} \mathrm{RuS}_{2}$ : C, 57.89; H, 4.37; N, 10.13 . Found: C, 57.43; H, 4.52; N, 9.93 .

2.2. Preparation of $\mathrm{TiO}_{2}$ Electrode. Nanocrystalline $\mathrm{TiO}_{2}$ photoelectrodes of about $20 \mu \mathrm{m}$ thickness (area: $0.25 \mathrm{~cm}^{2}$ ) were prepared using a variation of a method reported by Nazeeruddin et al. [15]. Fluorine-doped tin oxide-coated glass electrodes (Nippon Sheet Glass Co., Japan) with a sheet resistance of $8-10 \mathrm{ohm}^{-2}$ and an optical transmission of $>80 \%$ in the visible range were used. Anatase $\mathrm{TiO}_{2}$ colloids (particle size $\sim 13 \mathrm{~nm}$ ) were obtained from commercial sources (Ti-Nanoxide D/SP, Solaronix). The nanocrystalline $\mathrm{TiO}_{2}$ thin films of approximately $20 \mu \mathrm{m}$ thickness were deposited onto the conducting glass by screen printing. The film was then sintered at $500^{\circ} \mathrm{C}$ for $1 \mathrm{~h}$. The film thickness was measured with a Surfcom 1400A surface profiler (Tokyo Seimitsu Co. Ltd.). The electrodes were impregnated with a $50 \mathrm{mM}$ titanium tetrachloride solution and sintered at $500^{\circ} \mathrm{C}$. The dye solutions $\left(2 \times 10^{-4} \mathrm{M}\right)$ were prepared in $1: 1$ acetonitrile and tert-butyl alcohol solvents. Deoxycholic acid as a coadsorbent was added to the dye solution at a concentration of $20 \mathrm{mM}$. The electrodes were immersed in the dye solutions and then kept at $25^{\circ} \mathrm{C}$ for $20 \mathrm{~h}$ to adsorb the dye onto the $\mathrm{TiO}_{2}$ surface.

2.3. Fabrication of Dye-Sensitized Solar Cell. Photovoltaic measurements were performed in a two-electrode sandwich cell configuration. The dye-deposited $\mathrm{TiO}_{2}$ film was used as the working electrode and a platinum-coated conducting glass as the counter electrode. The two electrodes were separated by a surlyn spacer ( $40 \mu \mathrm{m}$ thick) and sealed up by heating the polymer frame. The electrolyte was composed of $0.6 \mathrm{M}$ dimethylpropyl-imidazolium iodide (DMPII), $0.05 \mathrm{M}$ $\mathrm{I}_{2}$, and $0.1 \mathrm{M} \mathrm{LiI}$ in acetonitrile.

2.4. Photovoltaic Characterization. The working electrode was illuminated through a conducting glass. The currentvoltage characteristics were measured using the previously reported method [16] with a solar simulator (AM-1.5, $100 \mathrm{~mW} / \mathrm{cm}^{2}$, WXS-155S-10: Wacom Denso Co. Japan). Monochromatic incident photon-to-current conversion efficiency (IPCE) for the solar cell, plotted as a function of excitation wavelength, was recorded on a CEP-2000 system (Bunkoh-Keiki Co. Ltd.).

\section{Results and Discussion}

Heteroleptic rythenium(II) complex SPS-02 was prepared by direct treatment of $\left[\mathrm{RuCl}_{2}(p \text {-cymene })\right]_{2}, 4,4^{\prime}$-Di-tertbutyl-2-2' -dipyridyl and 4,4'-dicarboxy-2,2'-biquinoline in refluxing DMF. Figure 2 shows the absorption spectrum of complex SPS-02 in ethanol.

The strong absorption band of the complex SPS-02 in the region between 250 and $350 \mathrm{~nm}$ are due to $\pi-\pi^{*}$ transitions. An intense and broad MLCT band at $619 \mathrm{~nm}$ with a shoulder at about $500 \mathrm{~nm}$ was observed for SPS-02. This enhanced red 


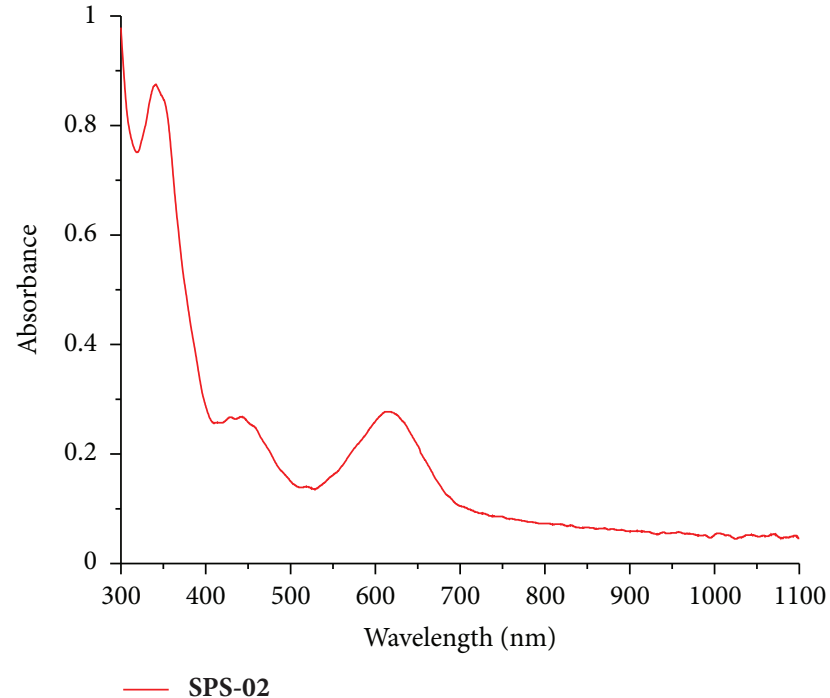

FIGURE 2: UV absorption spectra of SPS-02 in ethanol.

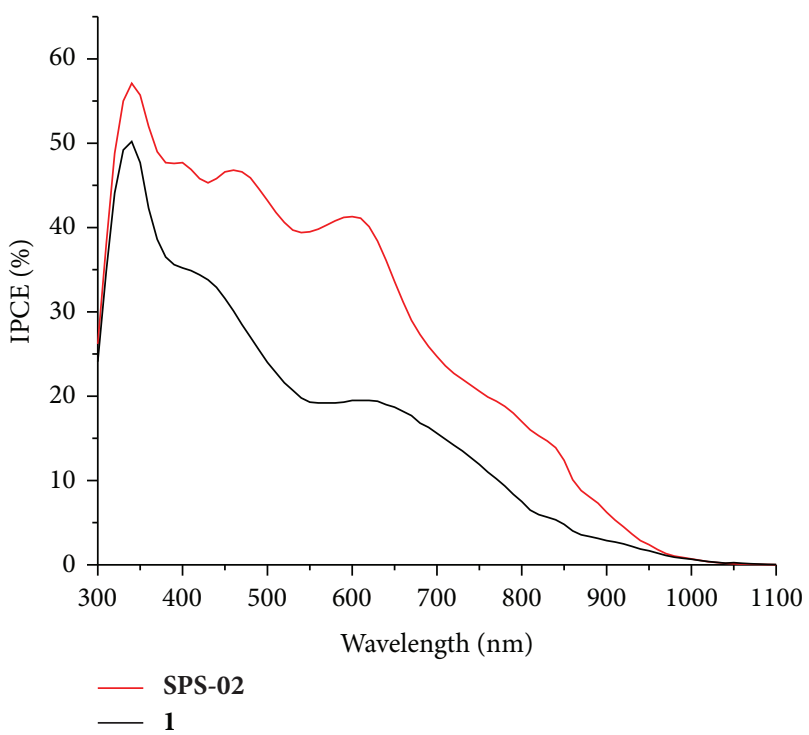

FIGURE 3: Photocurrent action spectra for SPS-02-sensitized and 1sensitized films of $\mathrm{TiO}_{2}$.

absorption of complex SPS-02 with MLCT band at $619 \mathrm{~nm}$ renders it attractive candidate as a panchromatic chargetransfer sensitizer for DSC application.

Figure 3 shows the photocurrent action spectra for complex SPS-02 where the incident photon-to-current conversion efficiency (IPCE) values are plotted as a function of wavelength. The photoresponse of thin films extends upto $1000 \mathrm{~nm}$. We observed an IPCE of 45\% in SPS-02 at about $610 \mathrm{~nm}$, while in the case of complex 1, the IPCE was $20 \%$. The DSC sensitized with complex SPS-02 exhibits superior light-harvesting properties in the near-IR region. The superior performance of SPS-02 was attributed to the superior light-harvesting efficiency of high- and low-energy photons.

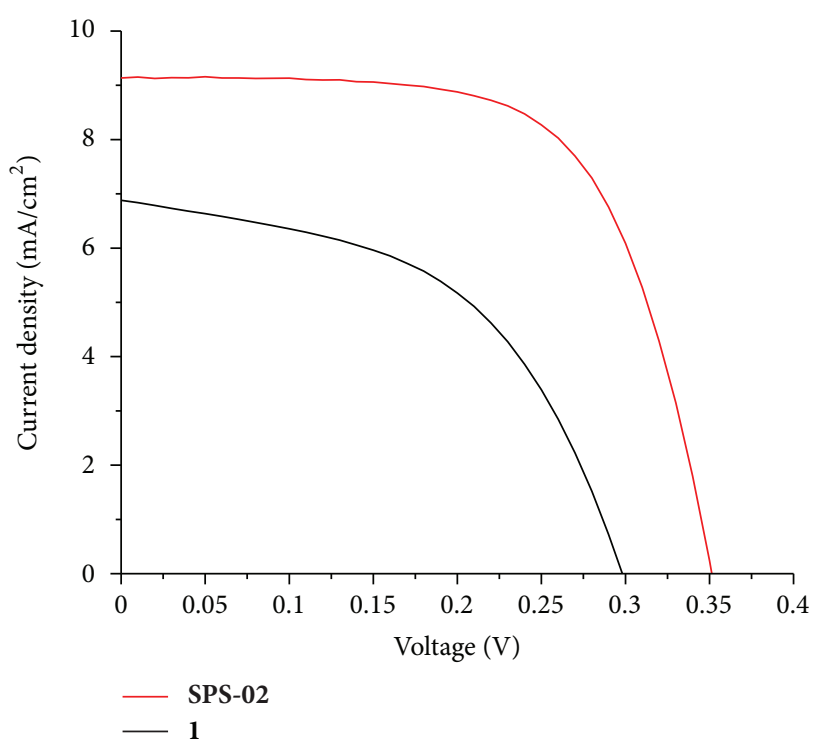

FIGURE 4: Photocurrent density-voltage characteristics of device SPS-02 and device $\mathbf{1}$ under air mass $1.5\left(100 \mathrm{~mW} \mathrm{~cm}^{-2}\right)$.

TABLE 1: Photovoltaic performance of complex SPS-02 and $\mathbf{1 .}$

\begin{tabular}{lcccc}
\hline Dye & $J_{\text {sc }}\left(\mathrm{mA} / \mathrm{cm}^{2}\right)$ & $V_{\text {oc }}[\mathrm{V}]$ & F.F. & Eff. $(\%)$ \\
\hline SPS-02 & 9.13 & 0.35 & 0.65 & 2.09 \\
$\mathbf{1}$ & 6.88 & 0.29 & 0.50 & 1.04 \\
\hline
\end{tabular}

Figure 4 shows a photocurrent density-voltage curve of a sealed solar cell based on complex SPS-02 and $\mathbf{1}$ under AM $1.5 \mathrm{G}$ simulated solar light at a light intensity of $100 \mathrm{~mW} \mathrm{~cm}^{-2}$ with a metal mask of $0.25 \mathrm{~cm}^{2}$. The photovoltaic performance of complex SPS-02 and $\mathbf{1}$ on nanocrystalline $\mathrm{TiO}_{2}$ electrode was studied using an electrolyte with a composition of $0.6 \mathrm{M}$ dimethylpropyl-imidazolium iodide (DMPII), $0.05 \mathrm{M} \mathrm{I}_{2}$, and $0.5 \mathrm{M}$ LiI in acetonitrile. The short-circuit photocurrent density $\left(J_{\mathrm{sc}}\right)$, open-circuit voltage $\left(V_{\mathrm{oc}}\right)$, fill factor $(\mathrm{FF})$, and overall cell efficiencies $(\eta)$ for test cells constructed from each dye are summarized in Table 1 . The test cell sensitized with complex SPS-02 showed a photocurrent density of $9.13 \mathrm{~mA} \mathrm{~cm}^{-2}$, an open circuit potential of $0.35 \mathrm{~V}$, and a fill factor of 0.65 , corresponding to an overall conversion efficiency $(\eta)$ of $2.09 \%$. Under similar fabrication and evaluation conditions, complex 1 gives $J_{\mathrm{sc}}=6.88 \mathrm{~mA} \mathrm{~cm}^{-2}, V_{\mathrm{oc}}=$ $0.29 \mathrm{~V}$, and $\mathrm{FF}=0.50$, corresponding to an overall conversion efficiency $(\eta)$ 1.04\%. Though the new Ru complex has spectral response in a wide energy range $(400-1000)$ the low value of short-circuit photocurrent $\left(J_{\text {sc }}\right)$ and cell efficiency $(\eta)$ are attributed to its low LUMO level which inhibits efficient electron injection on to the conduction band of $\mathrm{TiO}_{2}$.

\section{Conclusions}

A new ruthenium(II) complex containing cis- $\left[\mathrm{Ru}\left(\mathrm{H}_{2} \mathrm{dcbiq}\right)\right.$ $\left.(\mathrm{L})(\mathrm{NCS})_{2}\right]$, where $\mathrm{H}_{2} \mathrm{dcbiq}=4,4^{\prime}$-dicarboxy-2,2' -biquinoline and $\mathrm{L}=4,4^{\prime}$-Di-tert-butyl-2-2'-dipyridyl coded as 
SPS-02, was synthesized and characterized. This new dye exhibited efficient light-harvesting efficiency in a wide energy range (400-1000) which makes it as a potential photosensitizer for nanocrystalline $\mathrm{TiO}_{2}$ dye-sensitized solar cells. The performances of the dye-sensitized solar cells exhibited superior in terms of short-circuit photocurrent density $\left(J_{\mathrm{sc}}=9.13 \mathrm{~mA} \mathrm{~cm}^{-2}\right)$ and conversion efficiency $(\eta=2.09 \%)$ compared with complex 1 .

\section{References}

[1] B. O’Regan and M. Grätzel, "A low-cost, high-efficiency solar cell based on dye-sensitized colloidal $\mathrm{TiO}_{2}$ films," Nature, vol. 353, no. 6346, pp. 737-740, 1991.

[2] A. Hagfeld and M. Grätzel, "Light-induced redox reactions in nanocrystalline systems," Chemical Reviews, vol. 95, no. 1, pp. 49-68, 1995.

[3] M. Grätzel, "Conversion of sunlight to electric power by nanocrystalline dye-sensitized solar cells," Journal of Photochemistry and Photobiology A, vol. 164, no. 1-3, pp. 3-14, 2004.

[4] A. Hagfeld and M. Grätzel, "Molecular photovoltaics," Accounts of Chemical Research, vol. 33, no. 5, pp. 269-277, 2000.

[5] M. K. Nazeeruddin, A. Kay, I. Rodicio et al., "Conversion of light to electricity by cis-X2bis $\left(2,2^{\prime}\right.$-bipyridyl-4,4' -dicarboxylate)ruthenium(II) charge-transfer sensitizers (X=Cl-, $\mathrm{Br}-$-, I-, $\mathrm{CN}-$, and $\mathrm{SCN}-$ ) on nanocrystalline $\mathrm{TiO}_{2}$ electrodes," Journal of the American Chemical Society, vol. 115, no. 14, pp. 6382-6390, 1993.

[6] A. Hagfeldt, G. Boschloo, L. Sun, L. Kloo, and H. Pettersson, "Dye-sensitized solar cells," Chemical Reviews, vol. 110, no. 11, pp. 6595-6663, 2010.

[7] Y. Chiba, A. Islam, Y. Watanabe, R. Komiya, N. Koide, and L. Han, "Dye-sensitized solar cells with conversion efficiency of 11.1\%," Japanese Journal of Applied Physics, Part 2, vol. 45, no. 24-28, pp. L638-L640, 2006.

[8] A. Islam, H. Sugihara, L. P. Singh et al., "Synthesis and photophysical properties of ruthenium(II) charge transfer sensitizers containing 4,4'-dicarboxy-2,2' -biquinoline and 5,8-dicarboxy6,7-dihydro-dibenzo[1,10]-phenanthroline," Inorganica Chimica Acta, vol. 322, no. 1-2, pp. 7-16, 2001.

[9] S. P. Singh, A. Islam, M. Yanagida, and L. Han, "Development of a new class of thiocyanate-free cyclometalated ruthenium(II) complex for sensitizing nanocrystalline $\mathrm{TiO}_{2}$ solar cells," International Journal of Photoenergy, vol. 2011, Article ID 520848, 5 pages, 2011.

[10] A. Islam, S. P. Singh, and L. Han, "Thiocyanate-free, panchromatic ruthenium (II) terpyridine sensitizer having a tridentate diethylenetriamine ligand for near-IR sensitization of nanocrystaline $\mathrm{TiO}_{2}$," Functional Materials Letters, vol. 4, no. 1, pp. 21-24, 2011.

[11] A. Islam, S. P. Singh, M. Yanagida, M. R. Karim, and L. Han, "Amphiphilic ruthenium(II) terpyridine sensitizers with long alkyl chain substituted $\beta$-diketonato ligands: an efficient coadsorbent-free dye-sensitized solar cells," International Journal of Photoenergy, vol. 2011, Article ID 757421, 7 pages, 2011.

[12] P. Johansson, J. Rowley, A. Taheri et al., "Long-wavelength sensitization of $\mathrm{TiO}_{2}$ by ruthenium diimine compounds with lowlying $\Pi^{*}$ orbitals," Langmuir, vol. 27, no. 23, pp. 14522-14531, 2011.

[13] A. Islam, S. P. Singh, and L. Han, "Synthesis and application of new ruthenium complexes containing $\beta$-diketonato ligands as sensitizers for nanocrystalline $\mathrm{TiO}_{2}$ solar cells," International Journal of Photoenergy, vol. 2011, Article ID 204639, 8 pages, 2011.

[14] Md. Akhtaruzzaman, A. Islam, Y. Fan et al., "A novel metal-free panchromatic $\mathrm{TiO}_{2}$ sensitizer based on a phenylenevinyleneconjugated unit and an indoline derivative for highly efficient dye-sensitized solar cells," Chemical Communications, vol. 47, no. 45, pp. 12400-12402, 2011.

[15] M. K. Nazeeruddin, P. Péchy, T. Renouard et al., "Engineering of efficient panchromatic sensitizers for nanocrystalline $\mathrm{TiO}_{2}$ based solar cells," Journal of the American Chemical Society, vol. 123, no. 8, pp. 1613-1624, 2001.

[16] N. Koide and L. Han, "Measuring methods of cell performance of dye-sensitized solar cells," Review of Scientific Instruments, vol. 75, no. 9, pp. 2828-2831, 2004. 

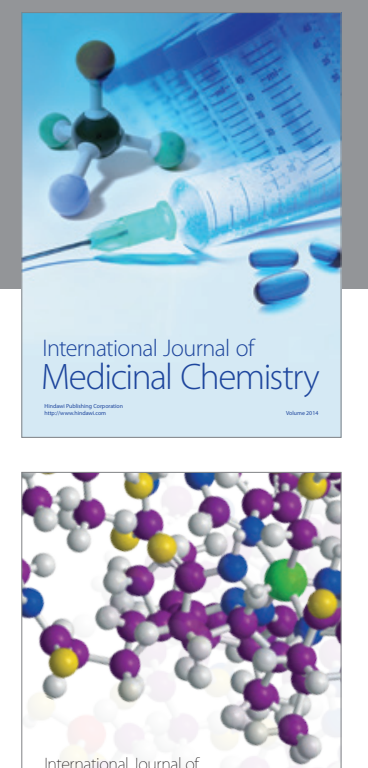

\section{Carbohydrate} Chemistry

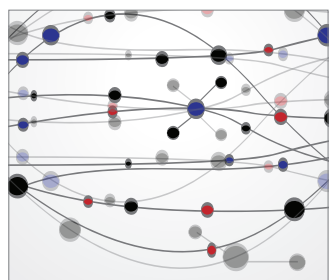

The Scientific World Journal
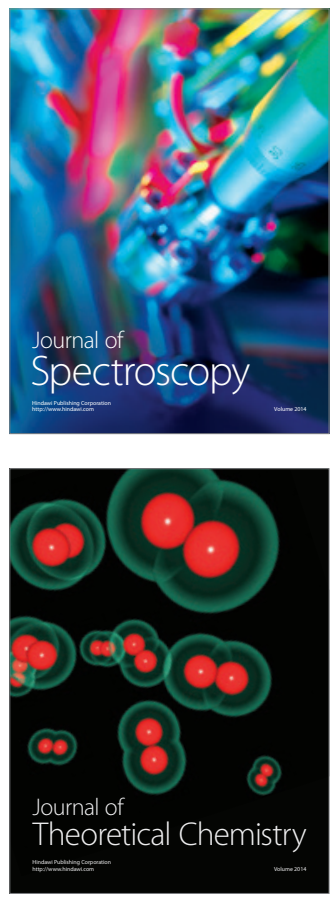
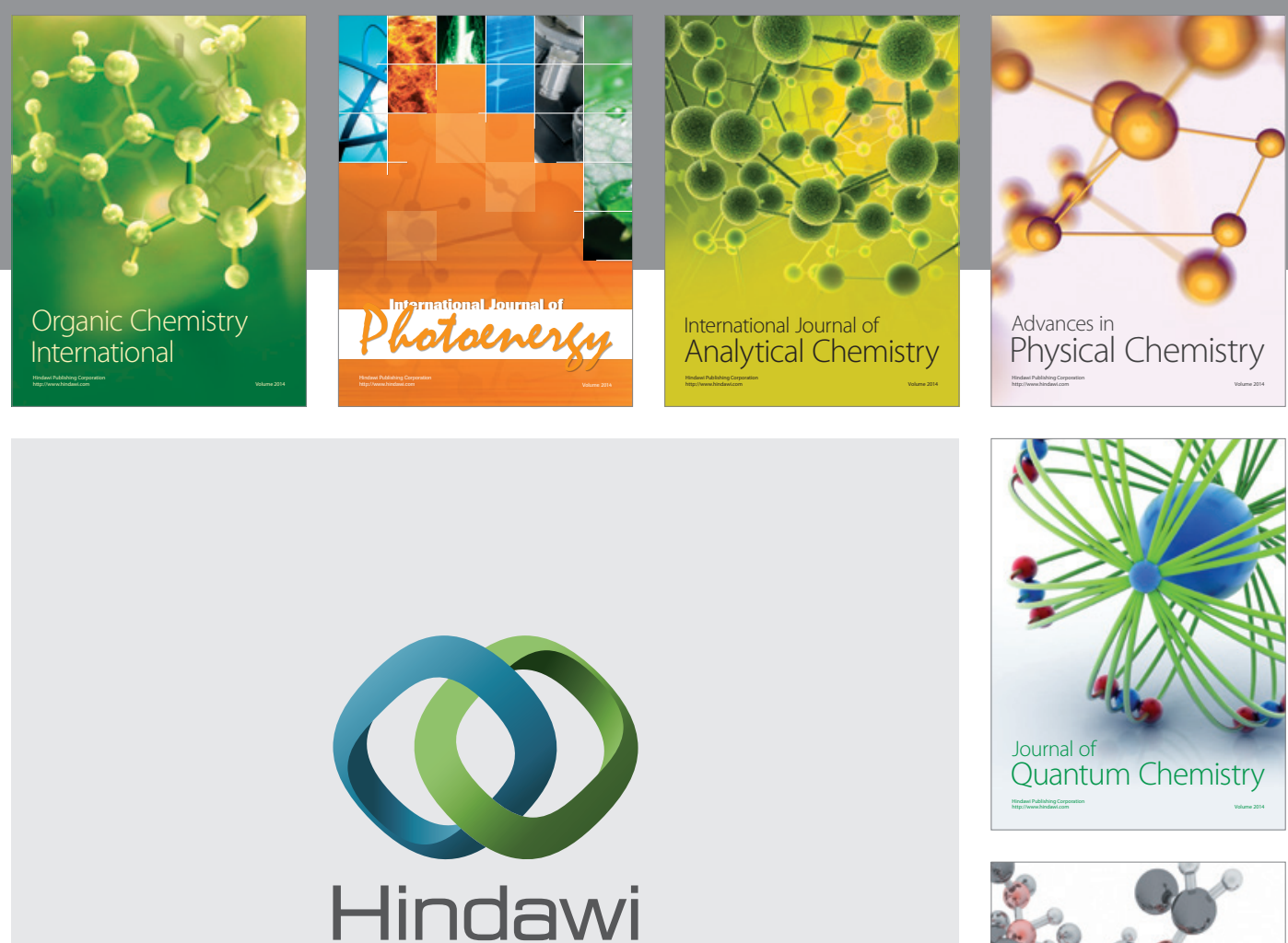

Submit your manuscripts at

http://www.hindawi.com

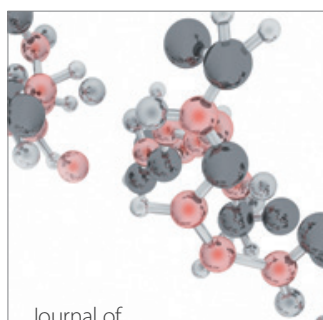

Analytical Methods

in Chemistry

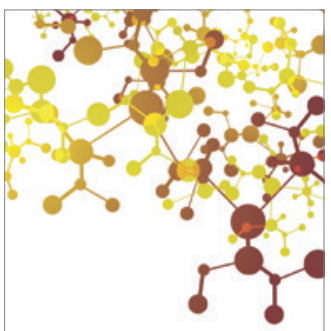

Journal of

Applied Chemistry

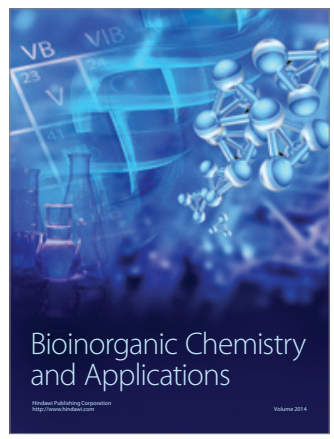

Inorganic Chemistry
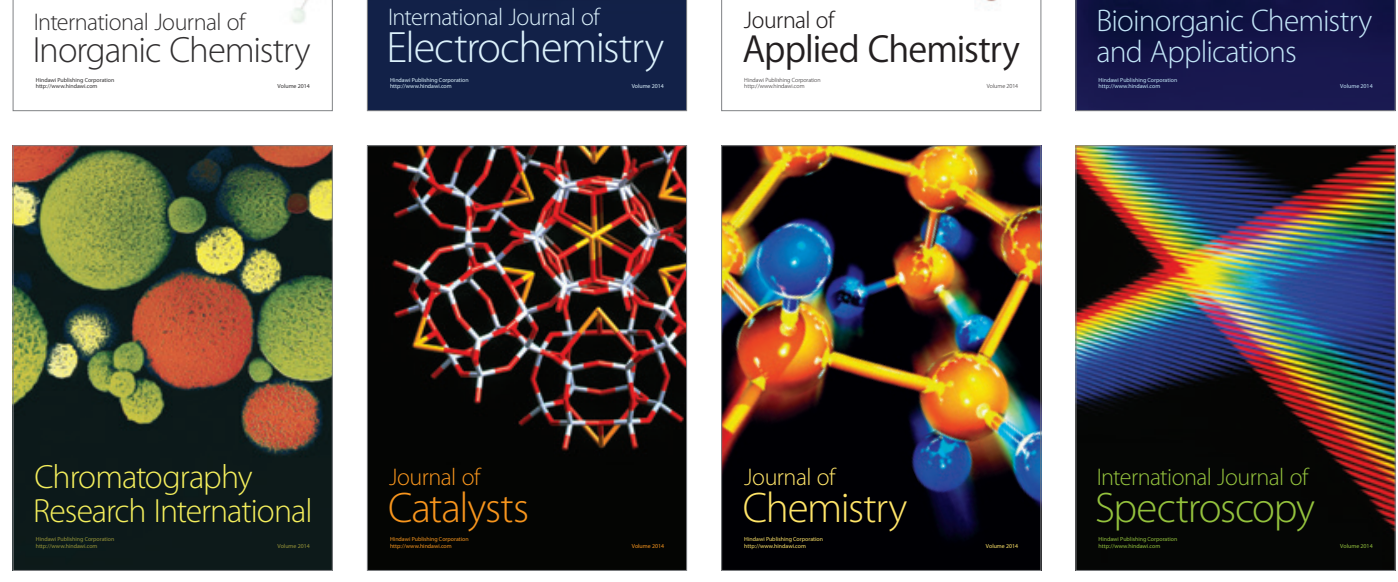